\title{
Transmission risk assessment of invasive fluke Fascioloides magna using GIS-modelling and multicriteria analysis methods
}

\author{
L. JUHÁSOVÁ1, I. KRÁLOVÁ-HROMADOVÁ1,", M. ZELEŇÁKOVÁ2, P. BLIŠŤAN, E. BAZSALOVICSOVÁ ${ }^{1}$
}

${ }^{1}$ Institute of Parasitology, Slovak Academy of Sciences, Hlinkova 3, 04001 Košice, Slovakia; ${ }^{2}$ Institute of Environmental Engineering, Technical University of Košice, Letná 9, 04200 Košice, Slovakia; Institute of Geodesy, Cartography and Geographical Information

Systems, Technical University of Košice, Letná 9, 04200 Košice, Slovakia

Article info

Received February 13, 2017 Accepted March 17, 2017

\begin{abstract}
Summary
The combination of multicriteria analysis (MCA), particularly analytic hierarchy process (AHP) and geographic information system (GIS) were applied for transmission risk assessment of Fascioloides magna (Trematoda; Fasciolidae) in south-western Slovakia. Based on the details on F. magna life cycle, the following risk factors (RF) of parasite transmission were determined: intermediate $\left(\mathrm{RF}_{\mathrm{IH}}\right)$ and final hosts $\left(\mathrm{RF}_{\mathrm{FH}}\right)$ (biological factors), annual precipitation $\left(\mathrm{RF}_{\mathrm{AP}}\right)$, land use $\left(\mathrm{RF}_{\mathrm{LU}}\right)$, flooded area $\left(R F_{F A}\right)$, and annual mean air temperature $\left(R_{A T}\right)$ (environmental factors). Two types of risk analyses were modelled: (1) potential risk analysis was focused on the determination of the potential risk of parasite transmission into novel territories (data on F. magna occurrence were excluded); (2) actual risk analysis considered also the summary data on F. magna occurrence in the model region (risk factor parasite occurrence $\mathrm{RF}_{\mathrm{PO}}$ included in the analysis). The results of the potential risk analysis provided novel distribution pattern and revealed new geographical area as the potential risk zone of $F$. magna occurrence. Although the actual risk analysis revealed all four risk zones of $F$. magna transmission (acceptable, moderate, undesirable and unacceptable), its outputs were significantly affected by the data on parasite occurrence what reduced the informative value of the actual transmission risk assessment.
\end{abstract}

Keywords: giant liver fluke; Trematoda; risk zone; Slovakia; parasite distribution

\section{Introduction}

The geographic information system (GIS) offers powerful tool for disease mapping, ecological analyses and epidemiological surveillance that has become indispensable for processing, analysing and visualising spatial data (Rinaldi et al., 2006). GIS allows analysis of multiple layers of map data in digital form, including earth-observation satellite data, with standard numerical data sets using computer-based statistical and image analysis methods (Burrough, 1986; Hugh-Jones, 1989). In parasitology, one of the most common GIS application is the evaluation of the results on occurrence and distribution of parasites in a form of digitalized maps in order to model the incidence of various parasites/parasitic diseases in the studied regions. A more complex GIS approach may be used for an assessment and quantification of their local risk. The risk assessment is based on variable factors, such as natural land cover (e.g. soil types), climate data, temperature, annual rainfall, and different land use categories (human settlements or protected areas, national parks, forest reserves, etc.) (Rinaldi et al., 2006).

The multicriteria analysis method (MCA) is widely used scientific approach, which may be implemented in the GIS environment for risk-mapping of populations or regions and for identification of risk zones. An analytical hierarchy process (AHP) is one of the most

\footnotetext{
$\bar{*}$ - corresponding author
} 
widely used multicriteria method based on the pairwise comparisons in order to create a ratio matrix and estimate a ranking or weighting of each of the evaluated criteria (Saaty, 1980). As for parasites, the integrated geospatial and multicriteria evaluation using highly specific AHP technique were used for determination of risk zones in a limited spectrum of parasites, e.g. for determination of epidemiologically highly important malaria risk zones in mosquito-borne diseases mapping (Bhatt \& Joshi, 2014). Concerning trematodes, risk assessment models using GIS environment based on the effect of annual climate variation on transmission intensity have been developed e.g. for fascioliasis (Malone et al., 1992).

Introduction of non-native (syn. non-indigenous, alien) species of parasites into novel territories may be accompanied by serious economic and/or environmental changes in original ecosystems (Pimentel et al., 2000). Aliens with tendency to spread and colonize new areas are classified as invasive species. The majority of introduction of invasive parasites is usually unintentionally mediated by anthropogenic activities, especially as a result of introduction of its final or intermediate hosts, e.g. by international trade, global transportation, markets or tourism (Lodge, 1993; Mack et al., 2000). The invasive parasites are capable to establish new populations and spread rapidly into new habitats, thus disseminating infective propagative stages into novel localities. The evaluation of threats caused by the alien parasites can represent a considerable challenge due to the limited information that often accompanies their introduction. Thus, studies on invasive species are important not only from parasitological point of view, but also from aspects on studies on biodiversity, ecology and environment. Within the last decade, a lot of information on biology, spatial distribution, and population genetics have been obtained for one of the remarkable invasive platyhelminth in Europe, giant liver fluke Fascioloides magna (Bassi, 1875), parasitizing a wide spectrum of free-living and domestic ruminants, mainly cervids and bovids (Králová-Hromadová et al., 2016). It is generally accepted that F. magna is of North American origin; it occurs in five enzootic areas across the United States and southern Canada, particularly in (a) northern Pacific coast; (b) Rocky Mountain trench; (c) northern Quebec and Labrador; (d) Great Lakes region; and (e) Gulf coast, lower Mississippi, and the southern Atlantic seaboard (Pybus, 2001). While the North American enzootic regions of F. magna are relatively stable, different situation is in Europe, where the parasite was several times introduced along with its cervid hosts and established three permanent natural foci (1) northwestern Italy; (2) Czech Republic and Poland; and (3) Danube floodplain forests (Králová-Hromadová et al., 2016). The original Italian focus has remained enclosed in the Regional Park La Mandria near Turin for more than 140 years (Bassi, 1875; Balbo et al., 1987; 1989, Apostolo, 1996); the two other European natural foci have shown dynamic changes in distribution of $F$. magna resulting in their enlargement. For a long time, the Czech focus was restricted only to the territory of Czech Republic (Ullrich, 1930; Leontovyč et al.,
2014). However, the very recent findings of $F$. magna confirmed the parasite expansion into new areas in Poland, in particular Lower Silesian Wilderness (Pyziel et al., 2014; Králová-Hromadová et al., 2015) and Podkarpackie Province (Karamon et al., 2015; Juhásová et al., 2016).

On the contrary, the Danube floodplain forests (DFF) represent dynamically expanding European natural focus of fascioloidosis even since the first F. magna findings in Austria (Pfeiffer, 1983), Slovakia (Rajský et al., 1994), and Hungary (Majoros \& Sztojkov, 1994). DFF represent an unique biotope providing optimal environmental conditions for intermediate (aquatic snails) and final (cervids) hosts of F. magna, and suitable ecological conditions for developmental stages of the parasite in exogenous environment (e.g. temperature, moisture, etc.). Consequently, giant liver fluke has been successfully spreading down the Danube River into novel territories, such as Croatia (Marinculić et al., 2002) and Serbia (Marinković et al., 2013). Fascioloides magna is apparently an invasive parasite with good ability to establish new natural focus (or enlarge the already established focus) in the presence of susceptible intermediate/final hosts important for a completion of the life cycle and favourable environmental conditions important for larval stages of the parasite in an exogenous environment.

In Slovakia, F. magna was first detected in the south-western part of the country in 1993 (Rajský et al., 1994). Since then, giant liver fluke has been regularly reported mainly around the Danube River flow, in area of floodplains and meadows near the Slovak-Hungarian border (Králová-Hromadová et al., 2016). To date, the predominant distribution area of $F$. magna is rather restricted to several districts of south-western Slovakia, where the fluke has regularly been reported (Bazsalovicsová et al., 2016).

Therefore, the principal aim of the current study was to evaluate a potential risk of transmission of $F$. magna beyond its current distribution zone along the Danube River into the broader geographical region in south-western Slovakia, for which biological and environmental factors important for F. magna development were evaluated. We were interested to find out if the model territory does provide a suitable environment for possible parasite development and if there is a risk of $F$. magna successful establishment in case of natural migration or man-made introduction of final host into the model region. From veterinary point of view, the risk analysis could also indicate a potential risk of a spread of infective stages of $F$. magna to domestic ruminants, which utilize grassland of model locality.

To achieve our objectives, the combination of multicriteria analysis (MCA) using analytic hierarchy process (AHP) method and geographic information system (GIS) were originally applied for the transmission risk assessment of $F$. magna. Based on the methodological specificities of procedures applied in the current work, two particular aims have emerged; (i) to identify key causal risk factors based on the overall knowledge on biology, life cycle, and environmental conditions of F. magna; and (ii) to determine the importance (weights) of individual risk factors using MCA and AHP 
Table 1. Specification of risk factors studied in transmission risk assessment of Fascioloides magna.

\begin{tabular}{ccc}
\hline Potential risk analysis & Code of risk factor & Actual risk analysis \\
Analysis without parasite occurrence & $(\mathrm{RF})$ & Analysis with parasite occurrence \\
\hline intermediate hosts & $\mathrm{RF}_{\mathrm{IH}}$ & intermediate hosts \\
final hosts & $\mathrm{RF}_{\mathrm{FH}}$ & final hosts \\
- & $\mathrm{RF}_{\mathrm{PO}}$ & parasite occurrence \\
annual precipitation & $\mathrm{RF}_{\mathrm{AP}}$ & annual precipitation \\
land use & $\mathrm{RF}_{\mathrm{LU}}$ & land use \\
flooded area & $\mathrm{RF}_{\mathrm{FA}}$ & flooded area \\
annual mean air temperature & $\mathrm{RF}_{\mathrm{AT}}$ & annual mean air temperature \\
\hline
\end{tabular}

methods. Due to the fact that the parasite occurrence in the model territory could affect the outcome of transmission risk assessment analysis, two types of risk analyses were modelled and evaluated; (1) the potential risk analysis (without parasite occurrence); and (2) the actual risk analysis (including data on parasite occurrence). Using giant liver fluke as the parasitic model species with complex life cycle, we aimed to compare the outputs of both analyses and to reveal the suitable methodological scheme for future transmission risk assessment analyses.

\section{Material and Methods}

\section{Potential and actual risk analyses}

The potential risk analysis was focused on determination of a potential risk of parasite transmission into novel territories. In this type of analysis, the data on F. magna occurrence were not included in the analysis and risk factor parasite occurrence $\left(\mathrm{RF}_{\mathrm{po}}\right)$ was excluded from the set of risk factors (Table 1). In the actual risk analysis, the summary data of 11-year monitoring of $F$. magna occurrence in south-western Slovakia performed in the period of 2005 - 2015 (Bazsalovicsová et al., 2016) and $\mathrm{RF}_{\mathrm{pO}}$ were included in the analysis (Table 1). It is important to highlight that data on $F$. magna occurrence, as presented by the mentioned authors, are selective since the survey study was targeted at localities with long-term high prevalence of fascioloidosis. The full-area survey, covering the entire model locality, has never been systematically performed.
According to the above review, the distribution of $F$. magna is centralized in three zones (Fig. 1): the first one is localized between the Gabčíkovo Waterworks and Dunajské luhy Protected Landscape Area in the Dunajská Streda District, second one is situated in south-western part of Komárno District near the border with Dunajská Streda District, and the third zone is present in the Komárno District in the north-eastern direction from Komárno town.

The transmission risk assessment was evaluated in four risk classes for both types of analyses; acceptable [1], moderate [2], undesirable [3] and unacceptable [4] (Table 2), which were arranged according to the MILSTD 882D Standard practice for system safety. Risk classes were divided using Tukey's quartile method.

\section{Studied model region}

As a base of the current work, the model region was selected according to summary knowledge on F. magna occurrence in south-western Slovakia (Bazsalovicsová et al., 2016; see Fig. 2). In addition, an adjacent and so far $F$. magna-free territory localized northerly from the endemic region was also included into the design of the model region. In particular, the model area represented a southern and south-western part of the Danube Lowland, situated between the inundation territory of the Danube River, the Little Carpathians and all other parts of the Western Carpathians, neighbouring with the Hungarian state border in the south and the Austrian state border in the western part of the Slovak Republic (Fig. 2). Model territory includes 13 districts (Malacky, Pezinok, Bratislava I, Bratislava II, Bratislava III, Bratislava IV, Bratisla-

Table 2. Risk classes of Fascioloides magna transmission risk assessment.

\begin{tabular}{|c|c|c|c|}
\hline Vulnerability rate & $\begin{array}{c}\text { Vulnerabilityl } \\
\text { acceptability }\end{array}$ & Significance of F. magna occurrence & $\begin{array}{c}\text { Scale of vulnerability } \\
\text { according to AHP }\end{array}$ \\
\hline$[1]$ & acceptable & $\begin{array}{c}\text { Vulnerability in region is acceptable - } \\
\text { current practice }\end{array}$ & $1.13-1.50$ \\
\hline$[2]$ & moderate & $\begin{array}{c}\text { Vulnerability in region is moderate - } \\
\text { condition of continual monitoring }\end{array}$ & $1.51-1.86$ \\
\hline$[3]$ & undesirable & $\begin{array}{c}\text { Vulnerability in region is undesirable - } \\
\text { protection measures }\end{array}$ & $1.87-2.23$ \\
\hline$[4]$ & unacceptable & $\begin{array}{c}\text { Vulnerability in region is unacceptable - } \\
\text { immediate protection }\end{array}$ & $2.24-2.60$ \\
\hline
\end{tabular}

$A H P$ analytic hierarchy process 


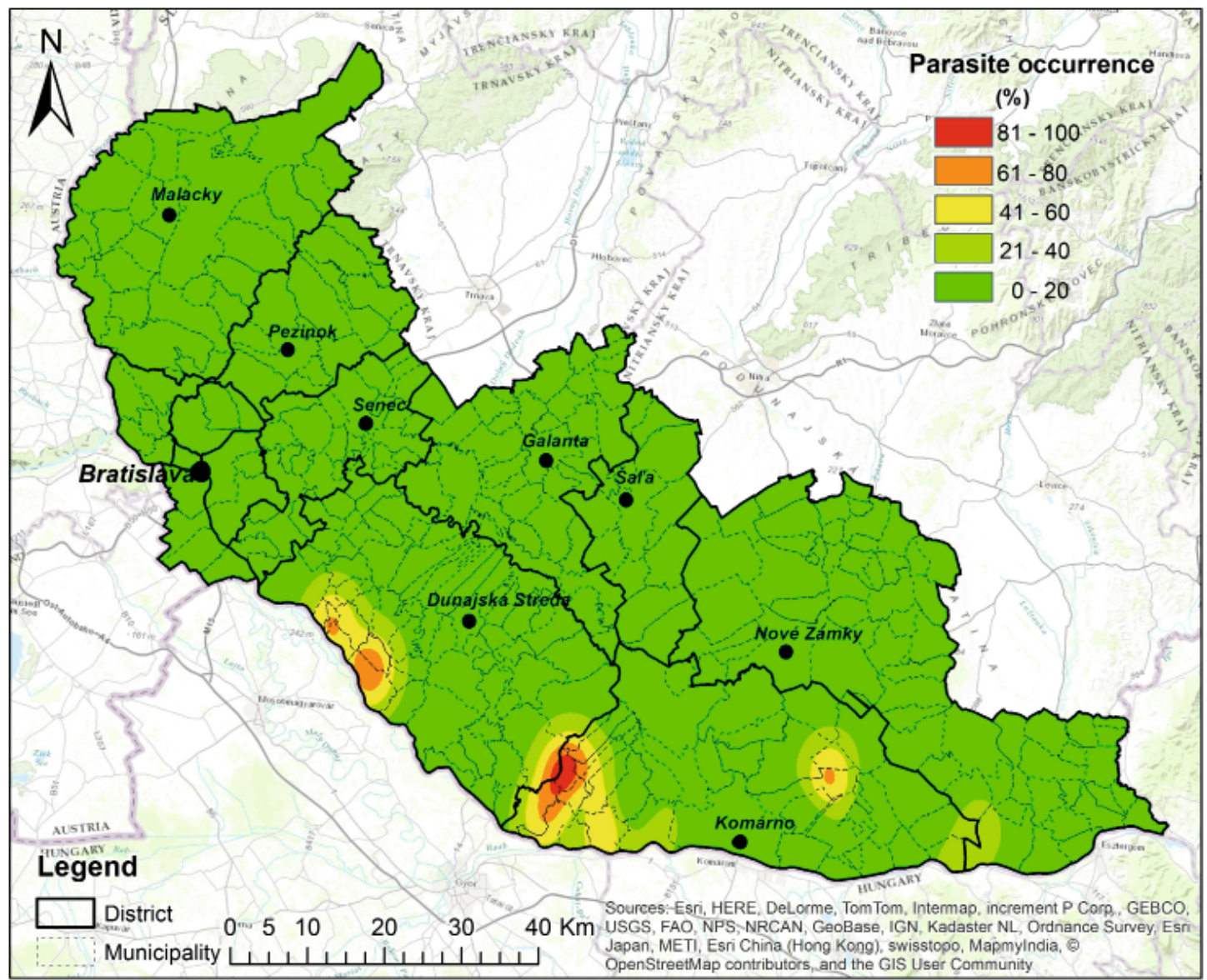

Fig. 1. The assessment of biological risk factor parasite occurrence $\left(\mathrm{RF}_{\mathrm{po}}\right)$ based on the summary data on the occurrence of Fascioloides magna in red deer (Cervus elaphus) in the model area published by Bazsalovicsová et al. (2016).

va V, Senec, Galanta, Šala, Dunajská Streda, Nové Zámky and Komárno) belonging to three Regions of Slovakia (Bratislava, Trnava and Nitra), reaching in total about $6,572 \mathrm{~km}$ square. The upper border of the studied area is formed by the northern line of districts Malacky, Pezinok and Senec (Bratislava Region). Model region includes also the entire flow of the Danube River in the territory of the Slovak Republic with around $172 \mathrm{~km}$ length, from which only $22 \mathrm{~km}$ do not create a state border. Model area included predominantly the majority of the Danube Lowlands, where almost entire analyzed territory is created by the Danubian Flat with an extensive river network formed by Váh, Nitra, Malý Dunaj, Hron and Danube rivers with adjacent smaller rivers, river branches and channels created by water activity.

The important part of the model area is represented by the Dunajské luhy Protected Landscape Area consisting of five separate parts along the inundation territory of the Danube River, stretching from Bratislava in the north-west near the border with Austria, following the main course of the Danube River in the south, up to the river island Vel'kolélsky ostrov in Komárno District on the Slovak-Hungarian border. Dunajské luhy Protected Landscape Area consists of more than $122 \mathrm{~km}$ square of protected floodplains, wetlands, and numerous of water bodies (e.g. lakes, oxbow lakes, ponds or streams). It represents a unique water habitat of many rare and protected aquatic plants and typical floodplain species (e.g. willows, alders, oaks, ashes, elms, poplars, European hornbeams and dogwoods), as well as a game habitat for number of protected molluscs, water birds, fish and mammals. Many terrestrial animals, especially different deer species (i.e. red deer, roe deer and fallow deer) have utilized floodplain biotope on both sides of the Danube River, where the natural conditions enable free movement and regular seasonal migration of animals between Slovakia and Hungary.

\section{Selection and determination of causal factors and their datasets}

The crucial factor in risk assessment analysis is determination of causal risk factors. In case of $F$. magna, the assessment of risk factors has resulted from biological and environmental factors of the parasite's complex life cycle which involves four stages (Fig. 3). The first developmental stage takes place in external environmental conditions, including the phase after dissemination of eggs within the host's faeces into water environment and hatching of miracidium. The second developmental stage involves different 


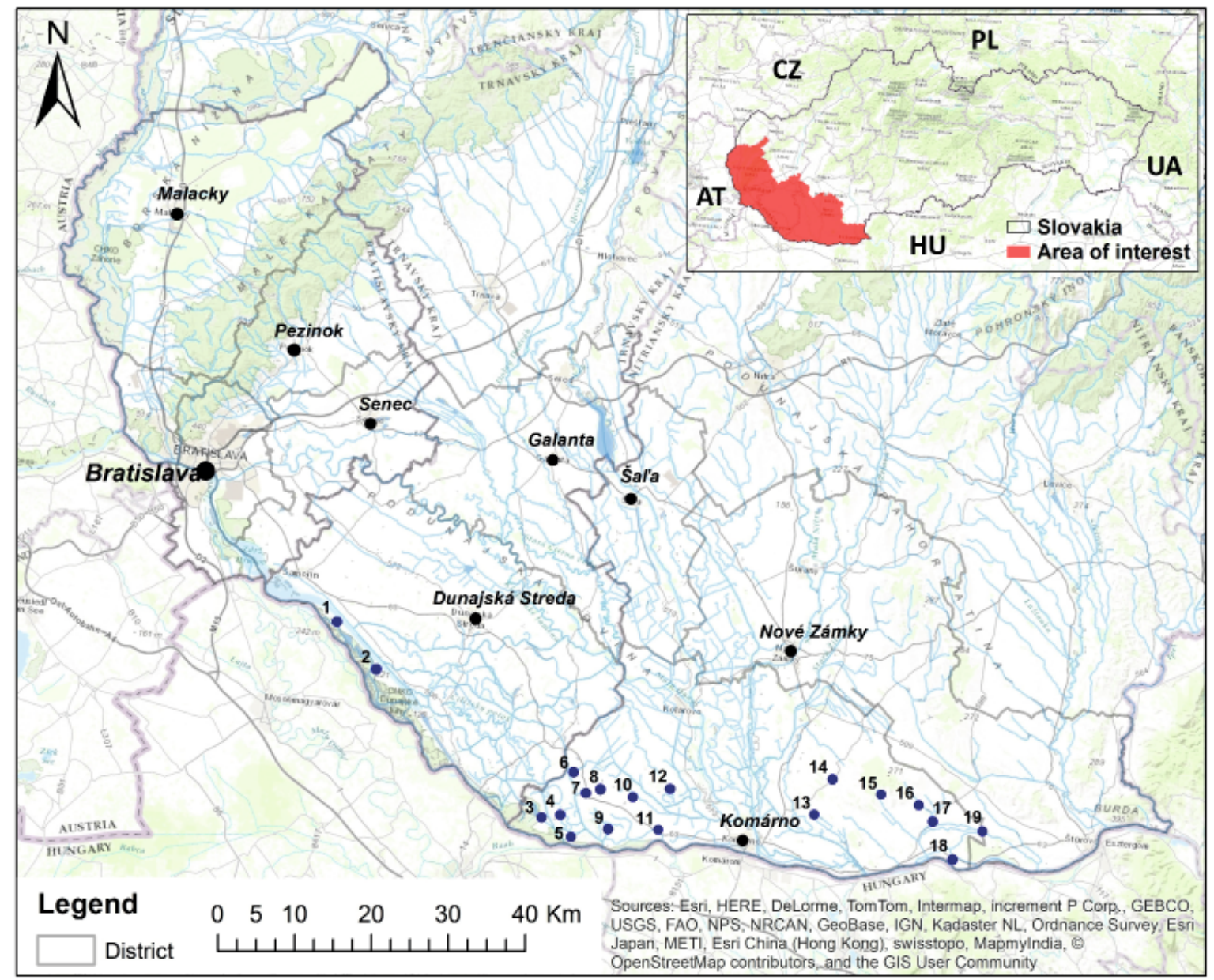

Fig. 2. The description of studied model region in south-western Slovakia analyzed in the current study. Points indicate localities with confirmed Fascioloides magna occurrence as resulted from the 11-year monitoring (Bazsalovicsová et al., 2016); (1) Vojka nad Dunajom, (2) Bodíky, (3) Číčov, (4) Trávnik, (5) Kližská Nemá, (6) Holiare, (7) Tôň, (8) Zemianska Olča, (9) Vel'ké Kosihy, (10) Okoličná na Ostrove, (11) Zlatná na Ostrove, (12) Čalovec, (13) Chotín, (14) Svätý Peter, (15) Modrany, (16) Bátorové Kosihy, (17) Búč, (18) Kravany nad Dunajom, (19) Svätý Juraj, Pereš. The respective localities were visualized using ArcGIS 9 version ArcView 9.3.

intramolluscan larval stages (sporocysts, mother and daughter rediae, cercariae) within the intermediate water snail hosts. In the third stage, metacercariae develop after release of cercariae from intermediate host in the humid external environment. The fourth stage begins after the ingestion of infective metacercariae by final hosts (e.g. cervids or other ruminants), and continues up to the maturity of adult flukes and production of eggs. The individual stages of life cycle of $F$. magna were described in detail by Erhardová-Kotrlá (1971). Based on the biological and environmental details of $F$. magna life cycle, the following risk factors were determined for risk assessment (Table 1):

- Risk factor - intermediate host $\left(\mathrm{RF}_{\mathbb{H}}\right)$

- Risk factor - final host $\left(\mathrm{RF}_{\mathrm{FH}}\right)$

- Risk factor - annual precipitation $\left(\mathrm{RF}_{\mathrm{AP}}\right)$

- Risk factor - land use $\left(\mathrm{RF}_{\mathrm{LU}}\right)$

- Risk factor - flooded area $\left(\mathrm{RF}_{\mathrm{FA}}\right)$

- Risk factor - annual mean air temperature $\left(\mathrm{RF}_{\mathrm{AT}}\right)$

The intermediate and final hosts are biological factors which result- ed from the life cycle. The annual precipitation, land use, flooded area and annual mean air temperature are environmental factors which have an impact on development of eggs, miracidia, cercariae and metacercariae in an exogenous environment.

The thematic maps were created for datasets of causative factors $\mathrm{RF}_{\mathrm{AP}}, \mathrm{RF}_{\mathrm{L}}, \mathrm{RF}_{\mathrm{FA}}, \mathrm{RF}_{\mathrm{AT}}$ and $\mathrm{RF}_{\mathrm{PO}}$, using the modelling and analysing tools in ArcGIS 9, version ArcView 9.3 - Geostatistical Analyst by the Kriging method. Each causative factor was categorized into the five classes and visualized (see Table 3). The classes for each risk factor were based on the biology, distribution, and life cycle of $F$. magna, along with data on physical and environmental conditions necessary for development of the parasite (Erhardová, 1961; Erhardová-Kotrlá, 1971; Pybus, 2001). Due to the fact that intermediate and final hosts of $F$. magna occur in the environment of the entire analysed territory of the Danube Lowland, these causative factors $\left(\mathrm{RF}_{\mid H}\right.$ and $\left.\mathrm{RF}_{\mathrm{FH}}\right)$ were not categorized and visualized in the map form; however, they were included into the assessment using AHP method. 


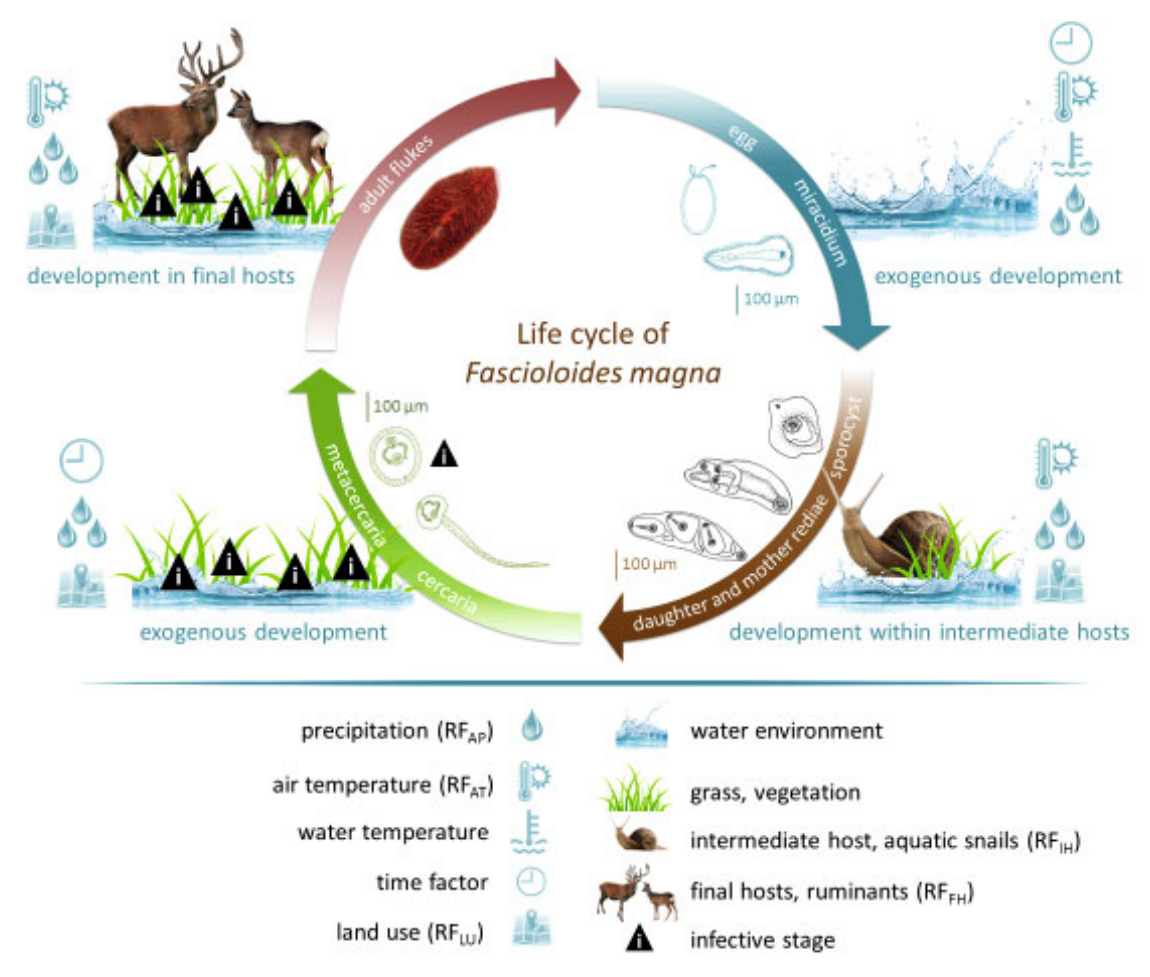

Fig. 3. The schematic life cycle of Fascioloides magna with biological and environmental factors.

Risk factor - intermediate host $\left(R F_{\mid H}\right)$

The complexity of the life cycle of $F$. magna and its ability to invade new region is ensured by the presence of suitable intermediate hosts, in particular aquatic pulmonate molluscs, in which larval development of the parasite takes place. While in North America six species of the family Lymnaeidae were found to be naturally infected with F. magna, only three snail species (Galba syn. Lymnaea truncatula, Radix labiata and Radix peregra) were proved to serve as intermediate hosts of $F$. magna in Europe (Králová-Hromadová et al., 2016). However, the only confirmed intermediate host of $F$. magna in Slovakia is aquatic snail $G$. truncatula. Since it is widely distributed in a natural environment throughout the entire model territory of the Danube Lowland (Horsák et al., 2016), a detailed map of $G$. truncatula occurrence was not provided. A suitable environment for maintenance and further spread of $G$. truncatula in the model area is assured by optimal landscape with flooded area, aquatic environment and sufficient annual precipitation.

Risk factor - final host $\left(R F_{F H}\right)$

F. magna parasitizes in a broad spectrum of final hosts, mainly free living and domestic ruminants. Final hosts of giant liver fluke are divided into three types (definitive, dead-end and aberrant) (Pybus, 2001) according to interrelationships between the parasite and the host, the ability of fluke to reach maturity and produce

Table 3. Determination of causative factors

\begin{tabular}{cccccc}
\hline Classes & \multicolumn{5}{c}{ Causative factors } \\
\hline & $\mathrm{RF}_{\mathrm{PO}}(\%)$ & $\mathrm{RF}_{\mathrm{AP}}(\mathrm{mm})$ & $\mathrm{RF}_{\mathrm{LU}}(-)$ & $\mathrm{RF}_{\mathrm{FA}}(-)$ & $\mathrm{RF}_{\mathrm{AT}}\left({ }^{\circ} \mathrm{C}\right)$ \\
\hline 1 & $0-20$ & $0-300$ & urbanized area & $\mathrm{no}$ & $-10-0$ \\
2 & $21-40$ & $301-700$ & agricultural land & & $0.1-6$ \\
3 & $41-60$ & $701-1,100$ & forest & & $6.1-11$ \\
4 & $61-80$ & $1,101-1,500$ & pastures and meadows & & $11.1-17$ \\
5 & $81-100$ & 1,501 and more & water area & yes & 17.1 and more \\
\hline
\end{tabular}

$R F_{P O}$ risk factor parasite occurrence, $R F_{A P}$ risk factor annual precipitation, $R F_{L U}$ risk factor land use, $R F_{F A}$ risk factor flooded area, $R F_{A T}$ risk factor annual mean air temperature 
eggs, pathological changes within the host organism, and the potential to release eggs of $F$. magna into external environment. From epidemiological point of view, only definitive hosts contribute significantly to further spread of propagative stages of $F$. magna into the environment. The most frequent definitive hosts of giant liver fluke in Europe are red deer (Cervus elaphus) and fallow deer (Dama dama) along with roe deer (Capreolus capreolus) classified as an aberrant host. In Slovakia, the most frequent definitive host of $F$. magna is red deer, in which the majority of $F$. magna infections have been detected (Králová-Hromadová et al., 2016). Based on Krištofík \& Danko (2012), there is an overall distribution of red deer in the natural environment of the model area with no significant natural landscape barriers which would limit its movement and migration. Consequently, a detailed map of $C$. elaphus occurrence was not provided.

\section{Risk factor - annual precipitation $\left(R F_{A P}\right)$}

Average values of total annual precipitation were provided by the Slovak Hydrometeorological Institute (SHMI) from total of 141 gauging stations in western Slovakia in the period of $1981-2015$. Mean numbers of annual precipitation ranged from $492.7 \mathrm{~mm}$ (in station Santovka) to $949.9 \mathrm{~mm}$ (in station Žarnovica). Partial data on the annual precipitation in individual stations are not listed.

Out of five classes of annual precipitation zones, the $2^{\text {nd }}$ and $3^{\text {rd }}$ classes were presented in model area, which represents one of the driest regions in Slovakia (Fig. 4A). Almost entire model terri- tory belongs to the area with an annual precipitation from 301 to $700 \mathrm{~mm}$ per year ( $2^{\text {nd }}$ class), except the forest belt area in the Little Carpathians in the north-western part of the model region, where the rainfall reached from 701 to $1,100 \mathrm{~mm}$ per year ( $3^{\text {rd }}$ class; see Fig. 4A).

Risk factor - land use $\left(R F_{L U}\right)$

The land use categories of the study area were obtained from the Corine Land Cover (2006, raster data), implemented in freely available database of the European Environment Agency according to the currently used mapping methodology. The majority of model territory is formed by agricultural areas (70 \%) with forest islands (16.2\%) stretching along the entire area (Fig. 4B). Large continuous forests are localized only in the north-western parts of the model region, and they form forests of the Záhorie Protected Landscape Area and the Little Carpathians. Urbanized area (8.3 $\%)$, pastures and meadows $(3.5 \%)$ are scattered throughout the whole model region, while large bodies of water $(2 \%)$ are located immediately next to the main flow of Danube, Váh and Hron rivers (see Fig. 4B).

\section{Risk factor - flooded area $\left(R F_{F A}\right)$}

According to 2007/60/EC Directive on the assessment and management of flood risks, the EU member states had an obligation to complete flood hazard maps and flood risk maps since December $22^{\text {nd }}, 2013$. Flood risk maps show the potential adverse conse-

Table 4. The matrix of pairwise comparison of causative criteria.

\begin{tabular}{|c|c|c|c|c|c|c|c|}
\hline \multicolumn{8}{|c|}{ Potential risk analysis } \\
\hline & $\mathrm{RF}_{\mathrm{HH}}$ & $\mathrm{RF}_{\mathrm{FH}}$ & $\mathrm{RF}_{\mathrm{PO}}$ & $\mathrm{RF}_{\mathrm{AP}}$ & $\mathrm{RF}_{\mathrm{LU}}$ & $\mathrm{RF}_{\mathrm{FA}}$ & $\mathrm{RF}_{\mathrm{AT}}$ \\
\hline $\mathrm{RF}_{\mathrm{IH}}$ & 1 & 1 & - & 5 & 5 & 5 & 7 \\
\hline $\mathrm{RF}_{\mathrm{FH}}$ & 1 & 1 & - & 9 & 5 & 7 & 7 \\
\hline $\mathrm{RF}_{\mathrm{AP}}$ & $1 / 5$ & $1 / 9$ & - & 1 & $1 / 5$ & 5 & $1 / 5$ \\
\hline $\mathrm{RF}_{\mathrm{LU}}$ & $1 / 5$ & $1 / 5$ & - & 5 & 1 & 5 & 5 \\
\hline $\mathrm{RF}_{\mathrm{FA}}$ & $1 / 5$ & $1 / 7$ & - & $1 / 5$ & $1 / 5$ & 1 & 5 \\
\hline $\mathrm{RF}_{\mathrm{AT}}$ & $1 / 7$ & $1 / 7$ & - & 5 & $1 / 5$ & $1 / 5$ & 1 \\
\hline Sum & 2.74 & 2.59 & - & 25.20 & 11.60 & 23.20 & 25.20 \\
\hline \multicolumn{8}{|c|}{ Actual risk analysis } \\
\hline & $\mathrm{RF}_{\mathrm{IH}}$ & $\mathrm{RF}_{\mathrm{FH}}$ & $\mathrm{RF}_{\mathrm{PO}}$ & $\mathrm{RF}_{\mathrm{AP}}$ & $\mathrm{RF}_{\mathrm{LU}}$ & $\mathrm{RF}_{\mathrm{FA}}$ & $\mathrm{RF}_{\mathrm{AT}}$ \\
\hline $\mathrm{RF}_{\mathrm{IH}}$ & 1 & 1 & 1 & 5 & 5 & 5 & 7 \\
\hline $\mathrm{RF}_{\mathrm{FH}}$ & 1 & 1 & 1 & 9 & 5 & 7 & 7 \\
\hline $\mathrm{RF}_{\mathrm{PO}}$ & 1 & 1 & 1 & 9 & 5 & 7 & 9 \\
\hline $\mathrm{RF}_{\mathrm{AP}}$ & $1 / 5$ & $1 / 9$ & $1 / 9$ & 1 & $1 / 5$ & 5 & $1 / 5$ \\
\hline $\mathrm{RF}_{\mathrm{LU}}$ & $1 / 5$ & $1 / 5$ & $1 / 5$ & 5 & 1 & 5 & 5 \\
\hline $\mathrm{RF}_{\mathrm{FA}}$ & $1 / 5$ & $1 / 7$ & $1 / 7$ & $1 / 5$ & $1 / 5$ & 1 & 5 \\
\hline $\mathrm{RF}_{\mathrm{AT}}$ & $1 / 7$ & $1 / 7$ & $1 / 9$ & 5 & $1 / 5$ & $1 / 5$ & 1 \\
\hline Sum & 3.74 & 3.59 & 3.56 & 34.20 & 16.60 & 30.20 & 34.20 \\
\hline
\end{tabular}

$R F_{I H}$ risk factor intermediate hosts, $R F_{F H}$ risk factor final hosts, $R F_{P O}$ risk factor parasite occurrence, $R F_{A P}$ risk factor annual precipitation, $R F_{L U}$ risk factor land use, $R F_{F A}$ risk factor flooded area, $R F_{A T}$ risk factor annual mean air temperature, Sum summary of individual criteria 


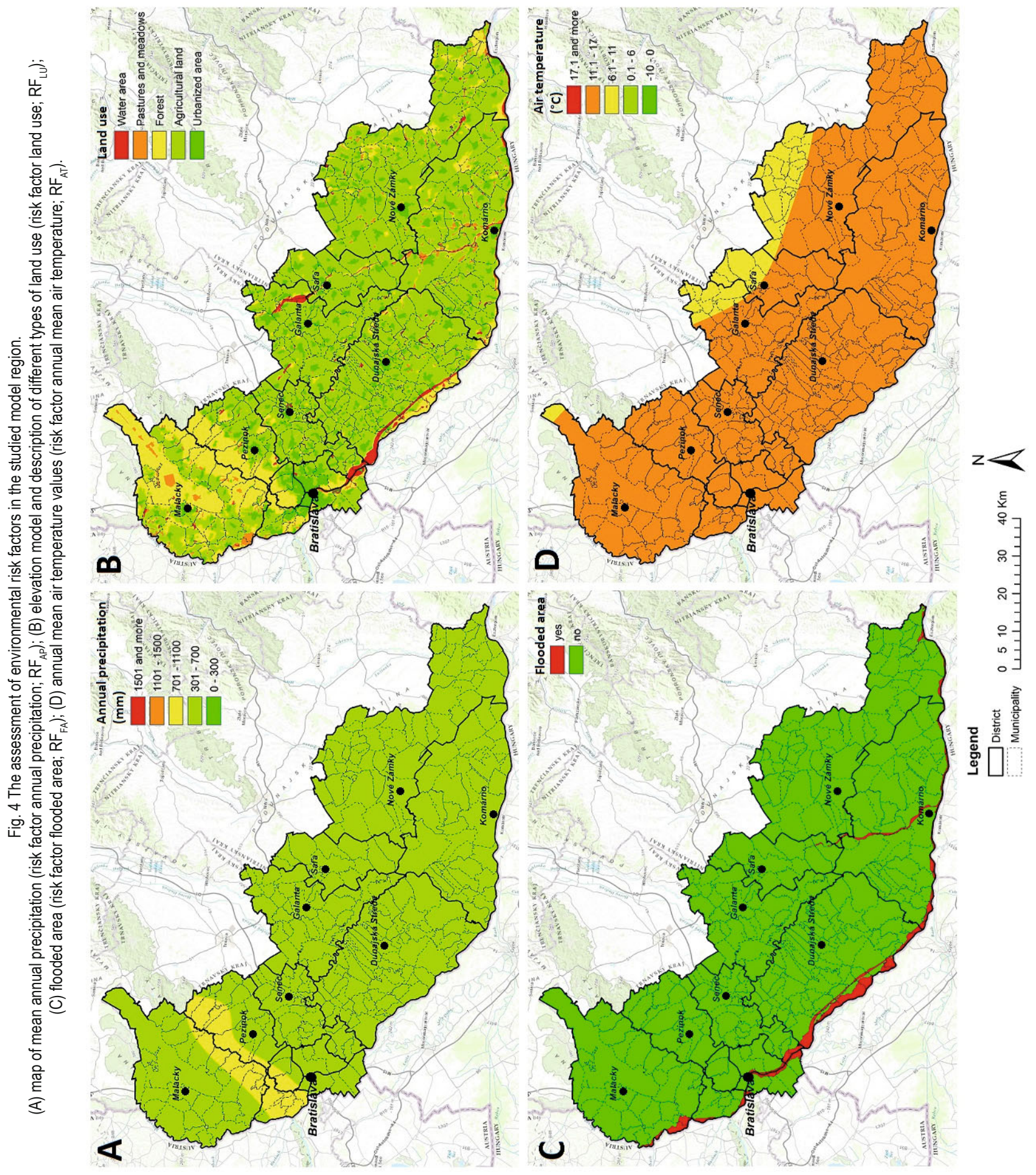


quences associated with flood scenarios. In Slovakia, flood risk maps were created by the Danish Hydraulic Institute (DHI Slovakia) according to the requirements of the Ministry of Environment of the Slovak Republic. The DHI Slovakia provided the flood risk map of Danube River for purposes of our research.

The flooded area occurs mainly in the basin of the Danube River and its tributaries. A left tributary of the Danube, the Morava River and its inundation territory around the Slovak-Austrian border, forms a flooded area west from Bratislava. The largest flooded area stretches along the main stream of the Danube River, directly along the Slovak-Austrian border, around the whole course of the river up to the lower end of the Danube at Slovak-Hungarian border (Fig. 4C). This area includes also the characteristic area of the Dunajské luhy Protected Landscape Area with island and semi-island regions of floodplains and meadows. Minor flooded areas are presented by the Váh River, which flows into the Danube near Komárno, and the Hron River flowing into the Danube further south near Štúrovo (see Fig. 4C).

Risk factor - annual mean air temperature $\left(R F_{A T}\right)$

Data on annual mean air temperature $\left(\mathrm{RF}_{\mathrm{AT}}\right)$ in the model area were obtained from five meteorological stations situated in south-western Slovakia, in particular from Bratislava airport, Gabčíkovo, Žihárec, Podhájska and Hurbanovo in the period of 1961 - 2015. Partial data on the annual mean air temperature in individual stations are not listed. Annual mean air temperature in the studied region varied from $-9.9^{\circ} \mathrm{C}$ to $+25.2^{\circ} \mathrm{C}$. Data were provided by the Slovak Hydrometeorological Institute (SHMI).

The model area includes only two of five annual mean air temperature categories (Fig. 4D). Almost all territory lies in the temperature range from $11.1^{\circ} \mathrm{C}$ to $17^{\circ} \mathrm{C}$. Only a small part of the analysed region, particularly northern border of districts Malacky, Galanta, Šala and Nové Zámky, occurs in range of $6.1^{\circ} \mathrm{C}$ to $11^{\circ} \mathrm{C}$ (see Fig. 4D).

\section{Analytic hierarchy process}

The analytic hierarchy process (AHP) developed by Saaty (1980) was applied for determination of the importance of selected causal factors. The matrix of pairwise comparison of causative criteria (Table 4) was used to assess the degree of significance of the individual criteria and measures, and to determine how the evaluated variants fulfil the resolution of these criteria. AHP method is a structured mathematical technique for organizing and analyzing complex decisions. Assessments are based on expert estimates by comparing the mutual influences of two or several causative factors based on the selected scale (Saaty, 1980) in order to obtain the relative importance of selected factors. The relative weight of selected criteria was based on an iterative process and the matrix of pairwise comparison (Table 5), where the matrix $\bar{A}$ of type $p \times p$ (i.e. it has $p$ rows and $p$ columns) was calculated by the normalization of the columns $A$ (Boroushaki \& Malczewski, 2008) according to the relation [1]:

$$
\bar{A}=\left[R F_{q t}^{*}\right]_{p \times p}
$$

For calculation of the element of the matrix $a_{q t}^{*}$ the relation applies [2]:

$$
R F_{q t}^{*}=\frac{R F_{q t}}{\sum_{q}^{p} R F_{q t}} \text { [2] }
$$

The matrix $\bar{A} \times \bar{A}$ was calculated and normalized in $\bar{A}_{2}$, subsequently $\bar{A}_{3}, \ldots, \bar{A}_{z}$ were calculated until all columns of the obtained matrix are identical. The column then gives the vector $\omega$ defined by the relation [3]:

$\omega_{q}=\overline{R F}_{q t(z)}^{*}$ for all $q=1,2, \ldots, p$

The verification of consistency for both types of analyses, for analysis without and with $\mathrm{RF}_{\mathrm{PO}}$, is carried out in the program Microsoft Excel and data are summarised in Table 6. It is important to know a certain measure of discrepancy, which arises with pair comparisons of the matrix $\bar{A}$. To assess the measure of consistency, it is necessary to calculate the so-called consistency index, Cl (Boroushaki \& Malczewski, 2008). Individual calculation was performed for analysis without parasite occurrence (Table 6, marked as "a"), and with parasite occurrence (Table 6, marked as "b"). The $\mathrm{Cl}$ index is calculated according to the relation:

$$
\begin{aligned}
& C l=\frac{\lambda-p}{p-1}=\frac{6.2447-6}{6-1}=0.04894 \\
& C I=\frac{\lambda-p}{p-1}=\frac{7.0165-7}{7-1}=0.00275
\end{aligned}
$$

The $\lambda$ value is the largest eigenvalue, which can be obtained as soon as we have its affiliated actual vector (according to [5]). The $p$ value is the number of criteria (columns) of matrix $\bar{A}$, where the total number of criteria for analysis without $\mathrm{RF}_{\mathrm{PO}}$ is $p=6(\mathrm{a})$ and with $\mathrm{RF}_{\mathrm{PO}}$ is $p=7$ (b).

$$
\lambda=\sum R F_{i} / \text { Weight }
$$

The consistency ratio $(C R)$ was calculated according to the relation (Boroushaki \& Malczewski, 2008):

$$
\begin{aligned}
& C R=\frac{C l}{R l}=\frac{0.04894}{1.24}=0.03947 \\
& C R=\frac{C l}{R l}=\frac{0.00275}{1.32}=0.0021
\end{aligned}
$$

The $R /$ value is the random index of consistency according to the number of evaluated criteria $p$ of matrix $\bar{A}$ based on the Table 6 . If the resulting consistency ratio is less than $0.1(C R<0.1)$, the 
Table 5. Calculation of normalized weight criteria for potential (without parasite occurrence) and actual (with parasite occurrence) analyses.

\begin{tabular}{|c|c|c|c|c|c|c|c|c|}
\hline \multicolumn{9}{|c|}{ Potential risk analysis } \\
\hline & $\mathrm{RF}_{\mathrm{HH}}$ & $\mathrm{RF}_{\mathrm{FH}}$ & $\mathrm{RF}_{\mathrm{PO}}$ & $\mathrm{RF}_{\mathrm{AP}}$ & $\mathrm{RF}_{\mathrm{LU}}$ & $\mathrm{RF}_{\mathrm{FA}}$ & $\mathrm{RF}_{\mathrm{AT}}$ & Weight \\
\hline $\mathrm{RF}_{\text {IH }}$ & 0.3650 & 0.3861 & - & 0.1984 & 0.4310 & 0.2155 & 0.2778 & 0.3041 \\
\hline $\mathrm{RF}_{\mathrm{FH}}$ & 0.3650 & 0.3861 & - & 0.3571 & 0.4310 & 0.3017 & 0.2778 & 0.3513 \\
\hline $\mathrm{RF}_{\mathrm{AP}}$ & 0.0730 & 0.0425 & - & 0.0397 & 0.0172 & 0.2155 & 0.0079 & 0.0642 \\
\hline $\mathrm{RF}_{\mathrm{LU}}$ & 0.0730 & 0.0772 & - & 0.1984 & 0.0862 & 0.2155 & 0.1984 & 0.1516 \\
\hline $\mathrm{RF}_{\mathrm{FA}}$ & 0.0730 & 0.0541 & - & 0.0079 & 0.0172 & 0.0431 & 0.1984 & 0.0652 \\
\hline $\mathrm{RF}_{\mathrm{AT}}$ & 0.1400 & 0.1400 & - & 5.0000 & 0.0400 & 0.0400 & 0.2000 & 0.0636 \\
\hline Sum & 1 & 1 & - & 1 & 1 & 1 & 1 & 1 \\
\hline \multicolumn{9}{|c|}{ Actual risk analysis } \\
\hline & $\mathrm{RF}_{\| \mathrm{H}}$ & $\mathrm{RF}_{\mathrm{FH}}$ & $\mathrm{RF}_{\mathrm{pO}}$ & $\mathrm{RF}_{\mathrm{AP}}$ & $\operatorname{RF}_{L U}$ & $\mathrm{RF}_{\mathrm{FA}}$ & $\mathrm{RF}_{\mathrm{AT}}$ & Weight \\
\hline $\mathrm{RF}_{\mathrm{IH}}$ & 0.2674 & 0.2786 & 0.2809 & 0.1462 & 0.3012 & 0.1656 & 0.2047 & 0.2286 \\
\hline $\mathrm{RF}_{\mathrm{FH}}$ & 0.2674 & 0.2786 & 0.2809 & 0.2632 & 0.3012 & 0.2318 & 0.2047 & 0.2594 \\
\hline $\mathrm{RF}_{\mathrm{PO}}$ & 0.2674 & 0.2786 & 0.2809 & 0.2632 & 0.3012 & 0.2318 & 0.2632 & 0.2693 \\
\hline $\mathrm{RF}_{\mathrm{AP}}$ & 0.0535 & 0.0306 & 0.0309 & 0.0292 & 0.0120 & 0.1656 & 0.0058 & 0.0460 \\
\hline $\mathrm{RF}_{\mathrm{LU}}$ & 0.0535 & 0.0557 & 0.0562 & 0.1462 & 0.0602 & 0.1656 & 0.1462 & 0.1049 \\
\hline $\mathrm{RF}_{\mathrm{FA}}$ & 0.0535 & 0.0390 & 0.0393 & 0.0058 & 0.0120 & 0.0331 & 0.1462 & 0.0469 \\
\hline $\mathrm{RF}_{\mathrm{AT}}$ & 0.0374 & 0.0390 & 0.0309 & 0.1462 & 0.0120 & 0.0066 & 0.0292 & 0.0449 \\
\hline Sum & 1 & 1 & 1 & 1 & 1 & 1 & 1 & 1 \\
\hline
\end{tabular}

ratio indicates an appropriate level of consistency of the pairwise comparison; if it is higher than $0.1(C R>0.1)$, the pairwise comparison is a fully inconsistent determination. The comparison of resulting consistency levels for both types of analyses was as follows:

condition: $\mathrm{CR}<0.1$

$$
\begin{aligned}
& 0.03947<0.1 \text { (a) } \\
& 0.0021<0.1(\mathrm{~b})
\end{aligned}
$$

The resulting consistency factors in both types of analyses are smaller than value 0.1 , what indicated that the level of consistency is appropriate, i.e. the importance of selected causal factors was determined correctly. This process can be calculated automatically in the Microsoft Excel, the same as in the Expert Choice (Expert Choice Quick Start Guide, 2000 - 2004) software called MultiCriteria Decision Analysis (MCDA).

\section{Results and Discussion}

Results on potential and actual risk analyses

The main outputs of the transmission risk assessment of F. magna are composite vulnerability maps (Fig. 5) generated for the model area and displaying categories of transmission risk zones of giant liver fluke in the studied model region. In the potential transmission risk analysis (without $\mathrm{RF}_{\mathrm{PO}}$ ), three levels of risk zones were detected: acceptable, moderate and undesirable (Fig. 5A). The majority of model area represented the lowest, acceptable risk level. The moderate risk zones were scattered throughout the whole territory, mainly in the north-western part of model area, in the Little Carpathians, Borská nížina and Záhorie Protected Landscape Area, but also around the Morava, Danube and Váh rivers inundation territories. The highest undesirable risk level was found in the main course of the Morava River in the west, the Váh River in the central part and the Danube River in the whole flow from south-western to south-eastern direction.

From all environmental causal factors evaluated in the analysis, the risk factor land use was the most important factor for risk assessment (weight 0.1516), while remaining environmental causal factors affected the risk analysis at about the same rate $(0.0636-$ 0.0652) (Table 5). Despite the fact that the distribution of intermediate and final hosts is in the entire analysed area, the risk factor

Table 6. Random index of consistency according to Saaty (1980).

\begin{tabular}{llllccccccc}
\hline NC & $\mathbf{1}$ & $\mathbf{2}$ & $\mathbf{3}$ & $\mathbf{4}$ & $\mathbf{5}$ & $\mathbf{6}$ & $\mathbf{7}$ & $\mathbf{8}$ & $\mathbf{9}$ & $\mathbf{1 0}$ \\
$\mathrm{RI}$ & 0 & 0 & 0.58 & 0.9 & 1.12 & 1.24 & 1.32 & 1.41 & 1.45 & 1.49 \\
$\mathrm{TA}$ & & & & & & $\mathrm{a}$ & $\mathrm{b}$ & & \\
\hline
\end{tabular}

$N C$ number of criteria, $R /$ random index of consistency, $T A$ type of analysis, a potential risk analysis, $b$ actual risk analysis 


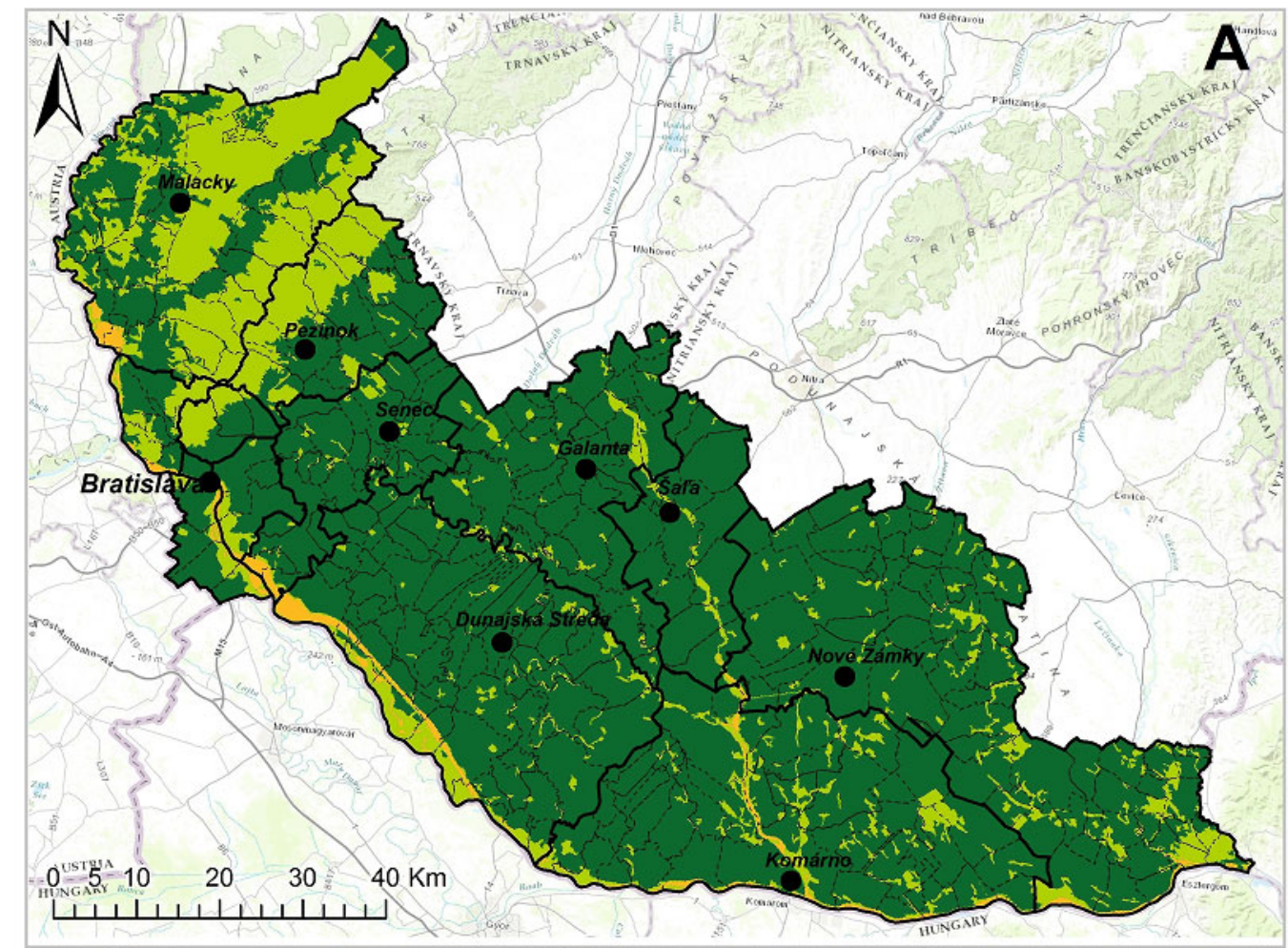

Risk analysis (Classes)
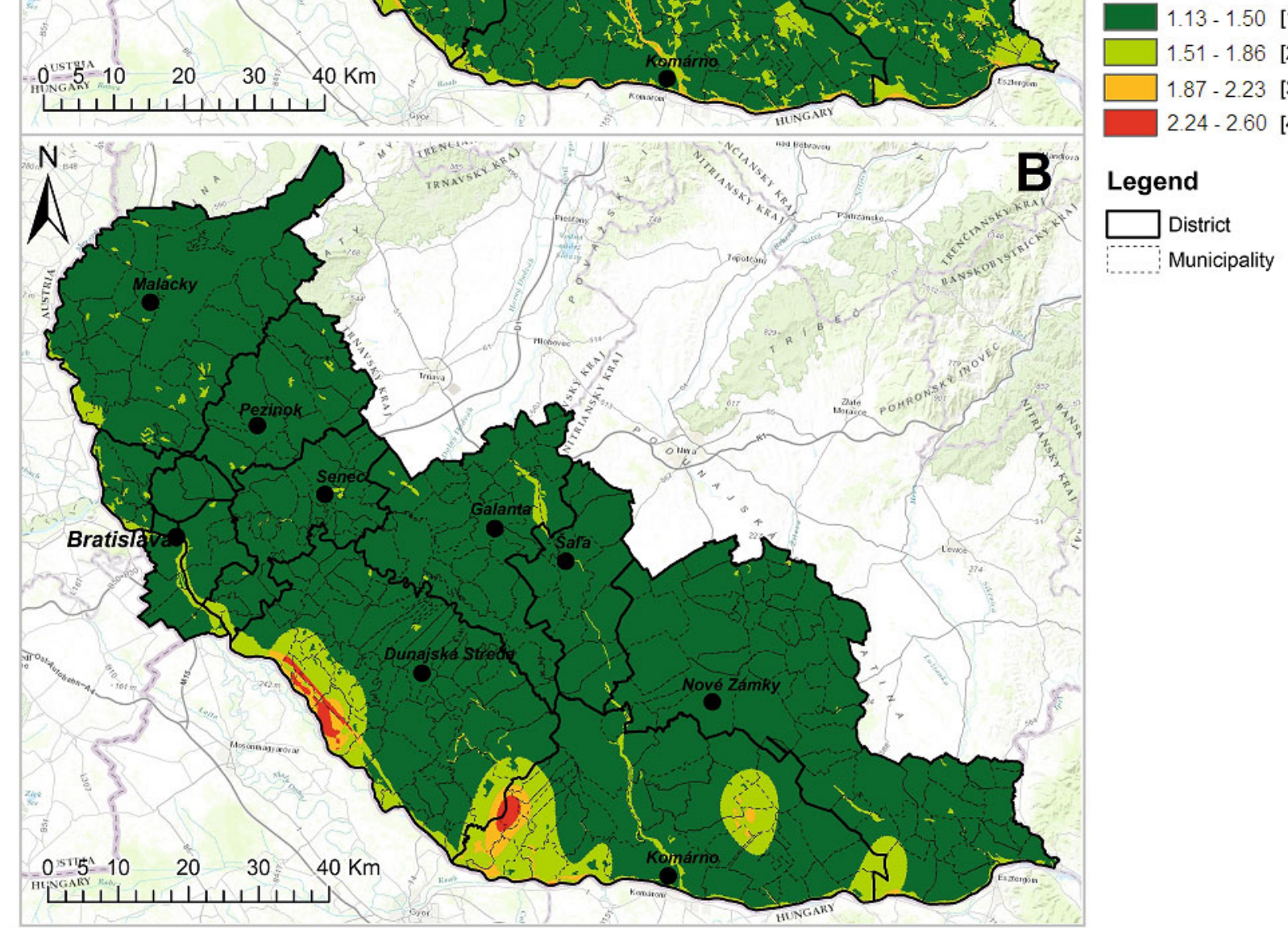

Fig. 5 The composite maps showing the transmission risk assessment of Fascioloides magna in model area created the analytic hierarchy process (AHP) method using ArcGIS 9.3. (A) potential risk analysis without parasite occurrence; (B) actual risk analysis with parasite occurrence. The calculated area percentages of particular vulnerability classes were $87.0 \%$ (acceptable), $11.5 \%$ (moderate), $1.0 \%$ (undesirable) and $0.5 \%$ (unacceptable), respectively. 
final host had a slightly higher impact on the risk analysis $\left(\mathrm{RF}_{\mathrm{FH}}\right.$; weight 0.3513$)$, in comparison with intermediate host $\left(\mathrm{RF}_{\mathbb{H}}\right.$; weight 0.3041) (see Table 5).

In the actual transmission risk analysis ( $\mathrm{RF}_{\mathrm{PO}}$ included), all four categories of risk zones were presented. Although the majority of analysed model region was again ranked in the lowest acceptable risk category (Fig. 5B), the distribution of other risk zones was rather different from those detected in the potential transmission risk analysis (Fig. 5A). The highest unacceptable risk zone was detected in the Dunajská Streda District in the inundation territory of the Danube River towards the Gabčíkovo Waterworks. This territory clearly corresponds with the Dunajské luhy Protected Landscape Area covering also the area of approximately $10 \mathrm{~km}$ from the Slovak-Hungarian border in the direction to Dunajská Streda (Fig. 5B). The second large focus of unacceptable risk zone is localized at the border between Dunajská Streda and Komárno districts. The first and second focus of unacceptable risk zones are surrounded by the moderate and undesirable risk zones. The third evident moderate risk zone with a small focus of undesirable risk zone was present in the region around $12 \mathrm{~km}$ north-eastern from Komárno in the Komárno District. The last moderate risk area was detected in the border between Komárno and Nové Zámky districts, extending up to the Slovak-Hungarian border in the south.

Congruently with the first analysis without $\mathrm{RF}_{\mathrm{PO}}$, the most important environmental risk factor in the actual transmission risk analysis was land use (weight 0.1049) (Table 5). The remaining environmental factors had approximately the same influence to the analysis (weight $0.0449-0.0469$ ) (Table 5). Concerning biological causative factors, the risk factor parasite occurrence had the highest impact to the analysis $\left(\mathrm{RF}_{\mathrm{PO}}\right.$; weight 0.2693$)$, while only slightly lower impact was recorded for final $\left(\mathrm{RF}_{\mathrm{FH}} ; 0.2594\right)$ and intermediate $\left(\mathrm{RF}_{\mathbb{H}} ; 0.2286\right)$ hosts.

\section{Comparison of results on potential and actual risk analyses}

The outputs of the actual transmission risk assessment (Fig. 5B) correlated well with the data on F. magna occurrence (Fig. 1) in the model region. It is evident that data on parasite occurrence strongly influenced the actual risk assessment analysis and the weight of risk factor $\mathrm{RF}_{\mathrm{PO}}$ was the highest one (0.2693; Table 5). From methodological point of view, this type of analysis only reproduced the data on parasite occurrence and we would not recommend it for risk assessment of $F$. magna in future. As already mentioned, data on parasite occurrence might be in general rather selective, targeted at localities with known prevalence of particular parasite, and full-area surveys, covering the entire model locality, are not frequently performed. Therefore, for more objective risk assessment, it is better to omit risk factor parasite occurrence from the analysis.

On the contrary, unique outputs resulted from the potential risk analysis, which provided different risk distribution pattern and more extensive geographical area was detected as a potential risk zone of $F$. magna occurrence (Fig. 5A). Interestingly, the current theoretical risk assessment study is apparently not only hypothetical. The newest data presented by Rajský et al. (2017) revealed presence of $F$. magna in Pezinok District, region which is situated inside the newly detected moderate risk zone resulting from the potential risk analysis. This finding underlines and highlights the results of risk assessment presented in the current work, in particular potential risk analysis.

In conclusion, the model area of south-western Slovakia provides a suitable environment for successful establishment and further development of $F$. magna in case of natural migration or manmade introduction of its final host into the model region. Once the region of giant liver fluke occurrence will be further enlarged, a risk of spread of $F$. magna infection to domestic ruminants will become actual. Therefore, constant and ongoing monitoring of F. magna occurrence in the model region is highly recommended.

\section{Acknowledgements}

This work was supported by project of the Scientific Grant Agency VEGA (project no. 2/0134/17) and Centre of Excellence for Parasitology (ITMS26220120022) (rate: 0.4) supported by the Research \& Development Operational Programme funded by the European Regional Development Fund.

\section{References}

Apostolo, C. (1996): The naturalistic aspects: flora, fauna and the environment. In: Lupo, M., Paglieri, M., Apostolo, C., Vaccarino, E., Debernardi, M. (Eds) La Mandria Storia e natura del Parco. Torino, Italy: Edizioni Eda, pp. 67 - 98

Balbo, T., Lanfranchi, P., Rossi, L., Meneguz, P.G. (1987): Health management of a red deer population infected by Fascioloides magna (Bassi, 1875) Ward, 1917. Ann Fac Med Vet Torino, 32: $1-13$

Balbo, T., Rossi, P., Meneguz, P.G. (1989): Integrated control of Fascioloides magna infection in northern Italy. Parassitologia, 31: $137-144$

BAssI, R. (1875): Sulla cachessia ittero-verminosa, o marciaia dei Cervi, causata dal Distomum magnum [On the cachexia induced by parasitic obstructive jaundice in deer, caused by Distomum magnum]. II Medico Veterinario, 4: 497 - 515

Bazsalovicsová, E., Špakulová, M., JuHÁsová, L'., Miholics, Š., RaJSKÝ, D., KRÁlovÁ-HROMADOVÁ, I. (2016): A long-term survey of Fascioloides magna in red deer (Cervus elaphus) in Slovakia (Danube floodplain forests) during the period of $2005-2015$. Helminthologia, 53(3): 243 - 247. DOI: 10.1515/helmin-2016-0024

BнAтT, B., Joshi, J.P. (2014): Analytical Hierarchy Process modelling for malaria risk zones in Vadodara District, Gujarat. In: The International Archives of the Photogrammetry, Remote Sensing and Spatial Information Sciences, Volume XL-8, ISPRS Technical Commission VIII Symposium, December 09-12, 2014. Hyderabad, India, 2014, pp. 171 - 176 
BoRoushaKI, S., MalCZEWSKI, J. (2008): Implementing an extension of the analytical hierarchy process using ordered weighted averaging operators with fuzzy quantifiers in ArcGIS. Comput Geosci., 34(4): 399 - 410. DOI: 10.1016/j.cageo.2007.04.003

Burrough, P.A. (1986): Principles of geographic information systems for land resources assessment. New York, NY, Oxford University Press, $194 \mathrm{pp}$.

ERHARDovÁ, B. (1961): Vývinový cyklus motolice obrovské Fasciola magna v podmínkách ČSSR [The life cycle of giant liver fluke Fascioloides magna in Czechoslovakia]. Folia Zool., 10: 9 - 16 (In Czech)

ERHARDOVÁ-KotRLÁ, B. (1971): The occurrence of Fascioloides magna (Bassi, 1875) in Czechoslovakia. Prague, Czech Republic, Czechoslovak Academy of Sciences, $155 \mathrm{pp}$.

Horsák, M., Čejka, T., JuŘičKová, L., Beran, L., HorÁČKová, J., HLAVÁč, J.Č., DVoŘÁK, L., HÁJeK, O., DivišEK, J., MaŇAs, M., LožEK, V. (2016): Check-list and distribution maps of the molluscs of the Czech and Slovak Republics. Retrieved December 12, 2016 from http://mollusca.sav.sk/malacology/checklist.htm

HugH-Jones, M. (1989): Applications of remote sensing to the identification of the habitats of parasites and disease vectors. Parasitol. Today, 5: $244-251$

JuhÁsová, L'., Bazsalovicsová, E., Králová-Hromadová, I., Karamon, J. (2016): A genetic structure of novel population of Fascioloides magna from Poland, Podkarpackie Province, indicates an expanding second European natural focus of fascioloidosis. Acta Parasitol., 61(4): 790 - 795. DOI: 10.1515/ap-2016-0109

Karamon, J., Larska, M., Jasik, A., Sell, B. (2015): First report of the giant liver fluke (Fascioloides magna) infection in farmed fallow deer (Dama dama) in Poland - pathomorphological changes and molecular identification. Bull Vet Inst Pulawy., 59: 339 - 344. DOI: 10.1515/bvip-2015-0050

Králová-Hromadová, I., Bazsalovicsová, E., Demiaszkiewicz, A. (2015): Molecular characterization of Fascioloides magna (Trematoda: Fascioloidae) from south-western Poland based on mitochondrial markers. Acta Parasitol., 60(3): 544 - 547. DOI: 10.1515/ ap-2015-0077

Králová-Hromadová, I., JuhÁsová, L'., Bazsalovicsová, E. (2016): The giant liver fluke, Fascioloides magna: Past, present and future research. Heidelberg, Germany, Springer International Publishing, $106 \mathrm{pp}$.

KRIŠTOFí, J., Danko, Š. (2012): Cicavce Slovenska: rozšírenie, bionómia a ochrana [The mammals of Slovakia: distribution, bionomy and protection]. $1^{\text {st }}$ Edition, Bratislava, Veda, 712 pp. (In Slovak)

Leontovyč, R., Košťáková, M., Siegelová, V., Melounová, K., PankRÁc, J., VRBovÁ, K., HoRÁK, P., KašnÝ, M. (2014): Highland cattle and Radix labiata, the hosts of Fascioloides magna. BMC Vet Res, 10: 1 - 7. DOI: 10.1186/1746-6148-10-41

LODGE, D.M. (1993): Biological invasions: lessons for ecology. Trends Ecol Evol., 8: 133 - 137
Mack, R.N., Simberloff, D., Lonsdale, W.M., Evans, H., Clout, M., BAzzAz, F.A. (2000): Biotic invasions: causes, epidemiology, global consequences, and control. Ecol Appl., 10: 689 - 710

Majoros, G., Sztoskov, V. (1994): Appearance of the American liver fluke Fascioloides magna (Bassi, 1875) (Trematoda: Fasciolata) in Hungary. Parasitol. Hungaria, 27: 27 - 38

Malone, J.B., Fehler, D.P., Loyacano, A.F., Zukowski, S.H. (1992): Use of LANDSAT MSS imagery and soil type in a geographic information system to assess site-specific risk of fascioliasis on Red River Basin farms in Louisiana. Ann N Y Acad Sci., 653: 389 - 397 Marinculić, A., Džakula, N., Janicki, Z., Hardy, Z., LuČinger, S., ŽIVIČNJAK, T. (2002): Appearance of American liver fluke (Fascioloides magna, Bassi, 1875) in Croatia - a case report. Vet. Arhiv, 72(6): $319-325$

Marinković, D., KukolJ, V., Aleksić-Kovačević, S., Jovanović, M., KNEŽEVIĆ, M. (2013): The role of hepatic myofibroblasts in liver cirrhosis in fallow deer (Dama dama) naturally infected with giant liver fluke (Fascioloides magna). BMC Vet. Res., 9: 45. DOI: 10.1186/1746-6148-9-45

Pimentel, D., Lach, L., Zuniga, R., Morrison, D. (2000): Environmental and economic costs of nonindigenous species in the United States. Bioscience, 50(1): 53 - 65

Pfeiffer, H. (1983): Fascioloides magna: Erster Fund in Österreich [The first finding of Fascioloides magna in Austria]. Wien. Tierarztl. Monat., 70: 168 - 170 (In German)

Pybus, M.J. (2001): Endoparasites. In: Samuel, W.M., Pybus, M.J., Kocan, A.A. (Eds) Parasitic Diseases of Wild Mammals. Volume 2. Ames, lowa: lowa State University Press, pp. 121 - 149

Pyziel, A.M., Demianszkiewicz, A.W., Kuligowska, I. (2014): Molecular identification of Fascioloides magna (Bassi, 1875) from red deer from south-western Poland (Lower Silesian Wilderness) on the basis of internal transcribed spacer 2 (ITS-2). Pol J Vet Sci., 17(3): $523-525$

RajskÝ, D., Patus, A., Bukovjan, K. (1994): Prvý nález Fascioloides magna (Bassi, 1875) na Slovensku [The first finding of Fascioloides magna (Bassi, 1875) in Slovakia]. Slov. Vet. Čas., 19: 29 - 30 (In Slovak)

RAJSkÝ, D., DANIHEL, L'., MAChÁČKovÁ, K. (2017): Cicavica obrovská: Barbarský parazit už stojí pred bránami Malých Karpát [The giant liver fluke: a barbarian parasite outside the gateway to Little Carpathians]. Polovníctvo a rybárstvo, 1/17: 44 - 45 (In Slovak)

Rinaldi, L., Musella, V., Biggeri, A., Cringoli, G. (2006): New insights into the application of geographical information systems and remote sensing in veterinary parasitology. Geospatial Health, 1: $33-47$

SAATY, T.L. (1980): The analytic hierarchy process: planning, priority setting, resource allocation. McGraw-Hill, New York, 437 pp. ULLRICH, K. (1930): Über das Vorkommen von seltenen oder wenig bekannten Parasiten der Säugetiere und Vögel in Böhmen und Mähren [The occurrence of rare or less known parasites of mammals and birds in Bohemia nad Moravia]. Prag Arch Tiermed., 10: 19 - 43 (In German) 